\title{
Modeling the Impact of Urbanization on Land-Use Change in Bahir Dar City, Ethiopia: An Integrated Cellular Automata-Markov Chain Approach
}

\author{
Melaku Bogale Fitawok ${ }^{1,2, *(\mathbb{D})}$, Ben Derudder ${ }^{1}$, Amare Sewnet Minale ${ }^{3}$, Steven Van Passel ${ }^{4}(\mathbb{D}$, \\ Enyew Adgo ${ }^{5}\left({ }^{-}\right.$and Jan Nyssen $1(\mathbb{D}$ \\ 1 Department of Geography, Ghent University, 9000 Gent, Belgium; Ben.Derudder@UGent.be (B.D.); \\ Jan.Nyssen@UGent.be (J.N.) \\ 2 Department of Economics, Bahir Dar University, P.O. Box 3052, Bahir Dar, Ethiopia \\ 3 Department of Geography and Environmental Studies, Bahir Dar University, P.O. Box 79, Bahir Dar, \\ Ethiopia; amare1974@gmail.com \\ 4 Department of Engineering Management, University of Antwerp, B-2610 Wilrijk-Antwerp, Belgium; \\ steven.vanpassel@uantwerpen.be \\ 5 Department of Natural Resource Management, Bahir Dar University, P.O. Box 79, Bahir Dar, Ethiopia; \\ enyewadgo@gmail.com \\ * Correspondence: Melaku.Fitawok@UGent.be; Tel.: +251-910768872
}

Received: 23 March 2020; Accepted: 8 April 2020; Published: 9 April 2020

\begin{abstract}
The fast-paced urbanization of recent decades entails that many regions are facing seemingly uncontrolled land-use changes (LUCs) that go hand in hand with a range of environmental and socio-economic challenges. In this paper, we use an integrated cellular automata-Markov chain (CA-MC) model to analyze and predict the urban expansion of and its impact on LUC in the city of Bahir Dar, Ethiopia. To this end, the research marshals high-resolution Landsat images of 1991, 2002, 2011, and 2018. An analytical hierarchy process (AHP) method is then used to identify the biophysical and socioeconomic factors underlying the expansion in the research area. It is shown that, during the period of study, built-up areas are rapidly expanding in the face of an overall decline of the farmland and vegetation cover. Drawing on a model calibration for 2018, the research predicts the possible geographies of LUC in the Bahir Dar area for 2025, 2034, and 2045. It is predicted that the conversions of other land-use types into built-up areas will persist in the southern, southwestern, and northeastern areas of the sprawling city, which can mainly be traced back to the uneven geographies of road accessibility, proximity to the city center, and slope variables. We reflect on how our findings can be used to facilitate sustainable urban development and land-use policies in the Bahir Dar area.
\end{abstract}

Keywords: analytical hierarchy process; cellular automata; land-use change; Markov chain; urbanization

\section{Introduction}

Urbanization and urban sprawl have become every-day realities across the world [1-3]. The world's cities are now home to more than half of the total world population [4], even though "urbanization" consists of variegated processes that unfold unevenly in time and space. Many developing countries-those in Africa, in particular-have recently begun rapidly urbanizing, with the urban population in Africa projected to triple by 2030 [5,6]. Furthermore, the continent is projected to be most rapidly urbanizing between 2020 and 2050 [6,7].

Many of these urban transition processes have resulted in the seemingly uncontrollable expansion of the urban fabric into the surrounding fringes. This, in turn, is often considered to adversely affect the ecosystem and poses major socio-economic challenges for a broad range of actors [1,8,9]. Many of these 
urban transition processes have resulted in the seemingly uncontrollable expansion of the urban fabric into the surrounding fringes. This is, in turn, often considered to be adversely affecting the ecosystem and posing major socio-economic challenges for a broad range of actors $[1,8,9]$. In particular, in many African cities, the absence and/or the implementation problem of spatial planning policies $[10,11]$ worsen the uncontrolled land-use changes, governance complexities, and widening socio-economic gaps across different scales [12-14].

Unsurprisingly, then, these LUCs have become a major point of attention in scientific research $[15,16]$. One salient area of research has been modeling the nature and the geographies of the massive conversion of "other" land-use types into built-up areas because of rapid urban expansion $[17,18]$. For example, previous studies have revealed that the built-up area expansion has predominantly been occurring by means of the conversion of agricultural land [19-21], forest [22], and open lands [23,24], depending on the context. These rapid and often uncontrolled and unplanned land use conversions have become a key challenge as they impact livelihoods in both the earlier communities and the newly emerging sprawl communities alike, and therefore ultimately the sustainability of the urban expansion at large $[13,18,25]$. Overall, it is clear that in many situations, rapid sprawl has created social, economic, and political instabilities that can be attributed to governance and land use policy issues $[12,14]$.

A scientific cornerstone in the understanding and subsequent mitigation of the challenges associated with the fast-paced urban expansion is the ability to understand and predict the expansion patterns as well as its key socioeconomic and environmental drivers [24]. Integrated cellular automata-Markov chain (CA-MC) models have arguably been some of the most commonly used spatiotemporal techniques in this regard. CA-MC models analyze how biophysical and socioeconomic variables impact LUC in and around cities. Furthermore, such models subsequently use these insights to predict the likely future trajectory of LUCs [26]. In many cases, a complementary analytical hierarchy process (AHP) is invoked to present a multi-criteria evaluation of the relative role of different factors to explain the expansion of a particular city [26-28]. Indeed, the application of such a model helps in revealing the trends, factors, and possible LUCs in a given area, acknowledging that these factors may be geographically specific. In practice, this is achieved by combining insight in processed high-resolution imageries, the potential factors influencing LUC, and a number of constraint variables in the urban expansion process. Several studies have applied this model in different geographical contexts [27,29,30]. For example, Mosammam [13] found a dramatic increase in the built-up area, mainly occurring along major roads and highways, resulting in an enormous decrease in agricultural land in Qom, Iran. Meanwhile, in a review paper by Aburas [31] focusing on CA-based simulation models, it was suggested that the integration of quantitative models such as MC and AHP could improve the accuracy of CA modeling and prediction. In this paper, we apply such an integrated CA-MC model with an AHP process for the purpose of modeling and predicting the geographies of the urban expansion around Bahir Dar, Ethiopia. We argue that the results of this research can help policymakers to implement more coherent and sustainable urban planning strategies as it allows us to capture both past and likely future trends.

In spite of Mundia and Murayama [32] affirming the applicability of the CA-MC model in developing countries, mainly due to the absence of reliable and accurate data, it has been rarely employed for analyzing Africa's urban expansion [12,23,32,33]. Against this backdrop, the primary objective of this research is to model and dissect the nature and geographies of urban expansion on LUCs in Bahir Dar by combining an integrated CA-MC model and the AHP technique of expert surveys.

\section{Materials and Methods}

\subsection{Study Area}

In spite of its booming capital city Addis Ababa, Ethiopia is presently still one of the least urbanized nations in Africa: its urbanization level is even below the East African sub-region average of 
25 percent [34]. Nonetheless, it has been moving towards becoming one of the most rapidly urbanizing countries in sub-Saharan Africa in general and in Eastern Africa in particular. According to the United Nations [35], its urban population was projected to increase annually by 4.6\% between 2015 and 2020 . In addition to extensive rural-urban migration, this urban boom has also been fueled by broader patterns of population growth $[13,36]$.

Bahir Dar City is one of the largest and most rapidly expanding cities in Ethiopia. It is the political, economic, and cultural center of Amhara National Regional State (ANRS), the second-most populous region in the country. In addition, the city is one of the major tourist centers in the country because of its cultural heritage (such as the Lake Tana Monasteries and religious festivals) and natural attractions (such as the Blue Nile Falls, birds, and hippos). The area is also characterized by rich biodiversity, and, as such, recognized as a Biosphere Reserve by UNESCO. According to data from the Central Statistics Agency [37], in 2017, about 350,000 people lived in the city. The city is located at $11^{\circ} 36^{\prime} \mathrm{N}$ latitude and $37^{\circ} 23^{\prime} \mathrm{E}$ longitude, at the southern shores of Lake Tana, the largest lake in Ethiopia. Thus, the research area consists of Bahir Dar city and parts of its surrounding rural fringes (locally termed "Kebeles"; Figure 1). Identifying the relevant potential zones of urban expansion in a modeling exercise is an important but difficult task; understanding the impact of built environment expansion requires identifying a relevant study area, but a clear and comprehensive spatial planning vision that could help identify this study area is lacking. We, therefore, adopted a pragmatic approach with a study area that is roughly defined by the lake to the north, the airport to the west, the Bezawit hilltop to the east, and the Sebatamit town border to the south.

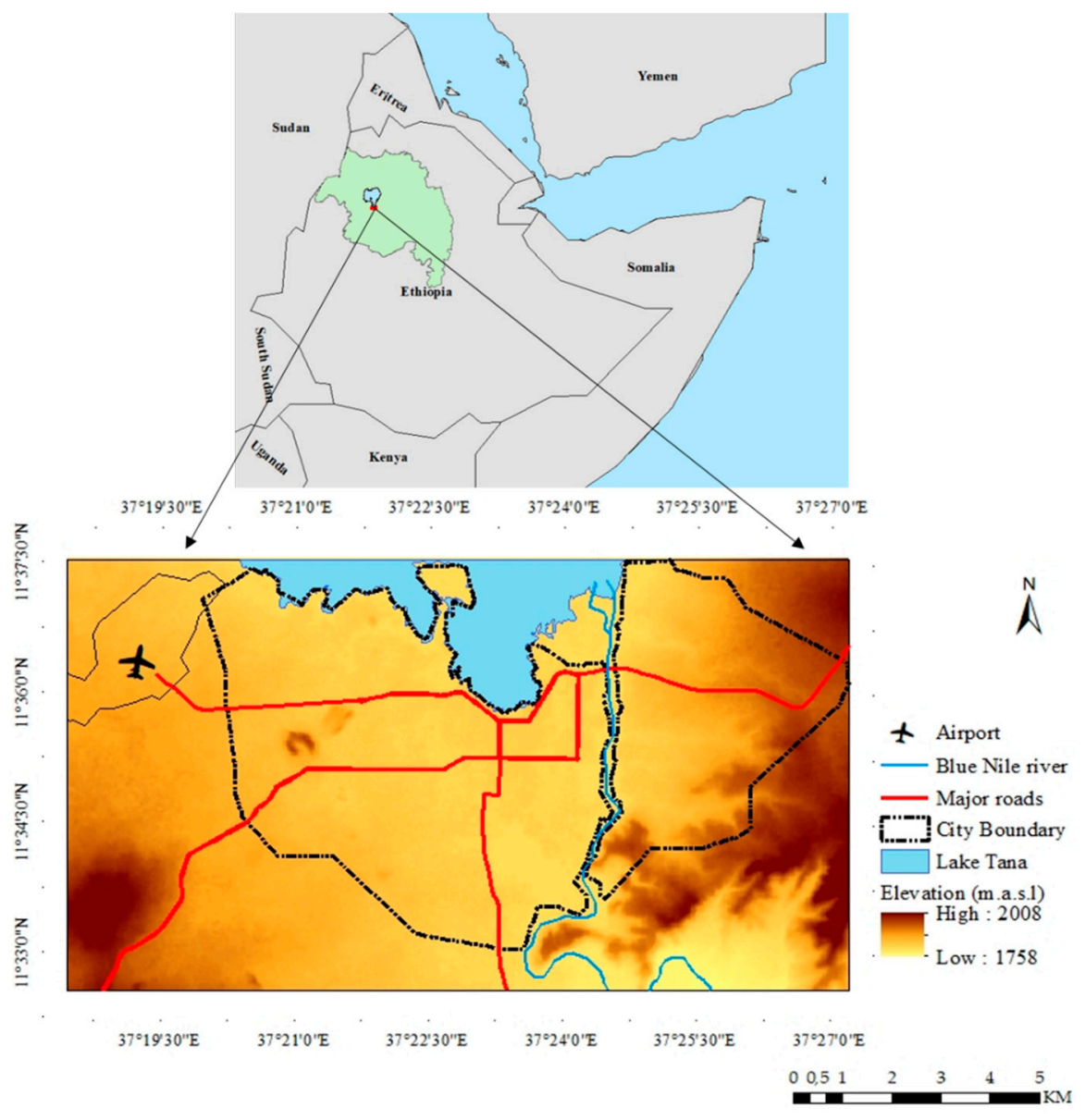

Figure 1. Location of the study area. 


\subsection{Data Sources}

We used a range of datasets to analyze LUCs in Bahir Dar (Table 1). As the United States Geological Survey (USGS) Landsat images are frequently updated and publicly available through Earth Explorer (http://earthexplorer.usgs.gov/) [24], in this study, we used the overtime Landsat images on a 30-m resolution for 1991, 2002, 2011, and 2018. These images have cloudiness of less than $10 \%$ and were acquired in the winter season in which the area experiences little cloud cover, and there are fewer atmospheric errors. We also gathered a digital elevation model (DEM) of $30 \mathrm{~m}$ resolution from the Advanced Spaceborne Thermal Emission and Reflection Radiometer (ASTER). This was, in turn, used to prepare a slope layer for the area. Finally, vector data for the major roads in the study area were collected from OpenStreetMap, and its geometric consistency was verified in QGIS software.

Table 1. Dataset sources and types.

\begin{tabular}{cccc}
\hline Dataset & Date & Source & Resolution \\
\hline Landsat 5 (Thematic Mapper) & 1991,2011 & U.S. Geological & \\
Landsat 7 (Enhanced Thematic Mapper Plus) & 2002 & Survey & $30 \mathrm{~m}$ \\
Landsat 8 (Operational Land Imager) & 2018 & ASTER (NASA) & $30 \mathrm{~m}$ \\
Digital Elevation Model (DEM), Slope & 2009 & OpenStreetMap & vector \\
Road & 2013 & Ope \\
\hline
\end{tabular}

\subsection{Methods}

Based on the overall analytical procedure set out in Figure 2, the extracted satellite images are projected into the WGS1984/UTM zone 37N system and subsequently classified via the maximum likelihood supervised image classification technique in ERDAS IMAGINE 15. The classification accuracy of the classified images is checked against random ground truth points. This is followed by the computation of an MC transition probability matrix of the area. Subsequently, the suitability map of each land-use class is developed using their corresponding factors and constraint variables, i.e., those factors identified by the AHP. Finally, the combined CA-MC model is validated and used for the prediction of future city expansion.

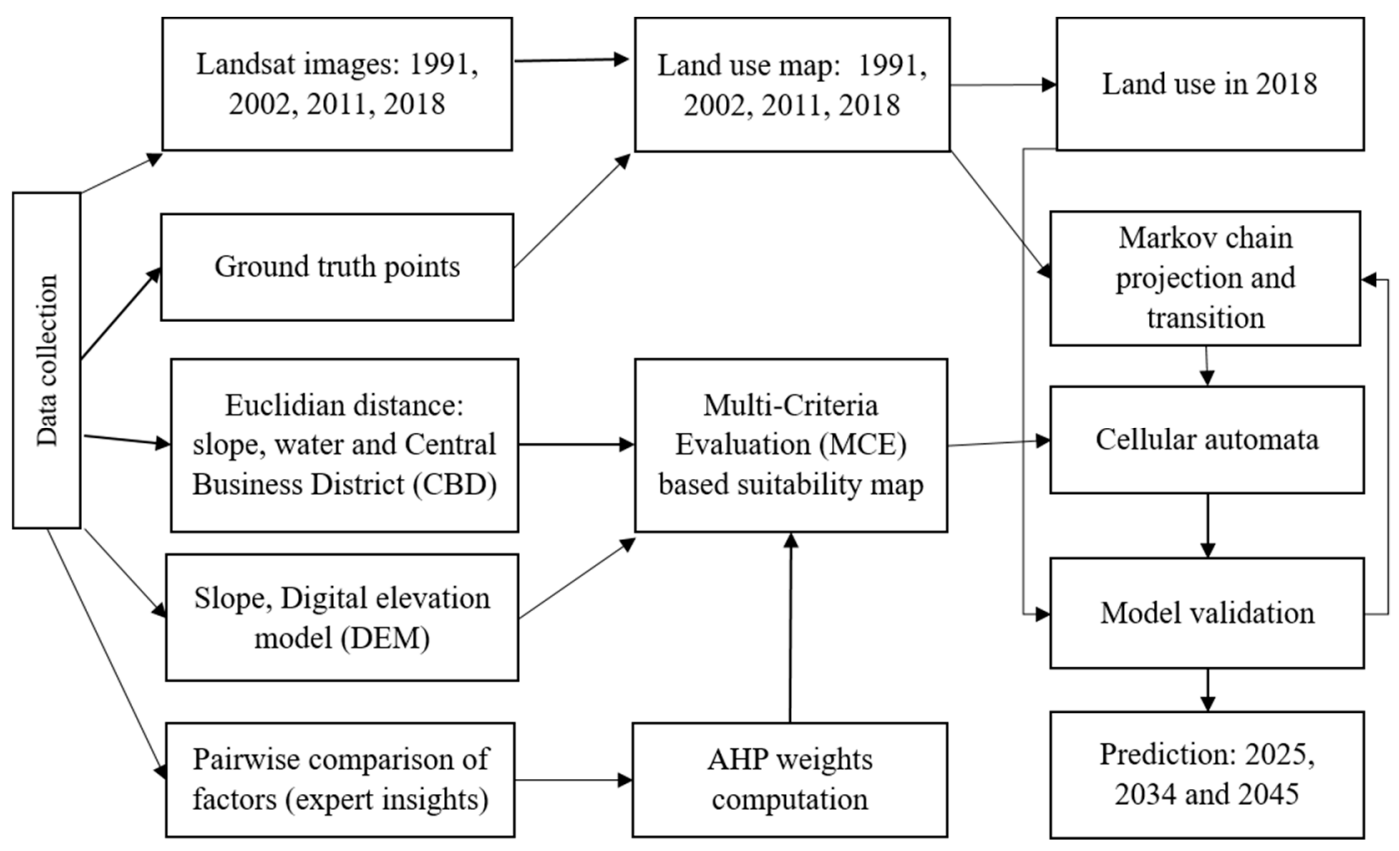

Figure 2. Flow chart for an integrated CA-MC model. 


\subsection{Land Use Classification}

Using a modified version of Anderson's often-used land use classification description [38,39], the satellite images for 1991, 2002, 2011 and 2018 were classified into five land use types: waterbodies, farmland, built-up areas, rangeland and forest (Table 2). We collected 150 random ground truth points for assessing the classification accuracy of the classified satellite images (i.e., 30 points for each land-use class identified below).

Table 2. Types of land use.

\begin{tabular}{cc}
\hline Land Use Classes & Description \\
\hline Waterbodies & Lakes, stream courses, reservoirs, and waterbodies \\
Farmland & Arable croplands and other agricultural lands \\
Built-up areas (urban) & Commercial and residential areas, road, and continuous built environment \\
Rangeland & Mixed or grass-covered open areas, barren land, shrubs, and wetlands \\
Forest (vegetation) & Trees, shrubs, semi-natural vegetation, and deciduous forest \\
\hline
\end{tabular}

\subsection{Urban Growth Model}

Measuring and, above all, modeling urban expansion and its impacts requires the exploitation of both (historical) remote sensing data and data on actual socioeconomic attributes $[2,8,13]$. Urban modeling thus enables policymakers and officials to understand and foresee the future expansion and helps in designing LUC policies better geared towards sustainable development $[18,31,40]$.

Previous research has, inter alia, applied various econometric models and spatial-based measurement frameworks for examining urban complexity and its multifaceted expressions [41,42]. Spatiotemporal models such as CA, MC, and SLEUTH (slope, land use, exclusion, transportation, and hill shade) techniques were applied in most of the previous studies for monitoring urban expansion $[43,44]$. In the present paper, we used an integrated CA-MC model that eliminates the shortcomings of individual (CA and MC) models [4].

\subsubsection{Cellular Automata (CA) Model}

$\mathrm{CA}$ is a simulation technique for modeling the dynamics of various complex phenomena using discrete models; it uses a countable outcome of a specific feature at a particular time $[43,45,46]$. This is achieved by representing spatial complexities in a grid/lattice of cells that have a specific land use $[15,47]$. To this end, CA models have four components: the cell, the state, the transition rule, and the neighborhoods [41]. The cell in CA is an element of a grid that represents a particular spatial shape and size on the ground. The state is any possible feature of a cell in the grid that represents the real characteristics of the area at a particular time (i.e., in this research, the land-use type). The neighborhood cells are the adjacent pixels: the cells that are the immediate neighboring cells of a particular cell in the grid. Finally, the transition rules spell out the transformation of cells into another state due to the change in neighborhood cells' status [2,22,48].

The application of the CA model shows the role of physical and environmental factors that restrict the urbanization process, assuming that the neighborhood cells also influence the state of a cell $[22,46,49]$. Therefore, the state of the specific plot of land on the ground (e.g., a water body such as a lake) is determined by some predefined transition rules (e.g., water bodies cannot be converted into the built-up area) as well as the state of the neighborhood cells [50].

\subsubsection{Markov Chain (MC) Model}

In this study, the MC model defines the scope of the spatiotemporal LUC, assuming the present cell's state depends on its historical land use and the likelihood of it changing into another form of land-use class $[12,16,47]$. The likelihood of changes is defined by a transitional probability matrix, 
which is computed from a series of historical land-use maps for each pixel changing [8,47]. Accordingly, the land-use transition probability between time $t$ and $t-1$ is computed as

$$
\mathrm{P}(\mathrm{t})=\mathrm{P}(\mathrm{t}-1) \mathrm{P}_{\mathrm{ij}}
$$

where $P(t)$ and $P(t-1)$ are the state probability of a cell at present and the previous point in time, respectively. $P_{i j}$ is the probability matrix of land-use type $i$ changing into land-use type j:

$$
P_{i j}=\left|\begin{array}{lll}
P_{11} & P_{12} \cdots & P_{1 n} \\
P_{21} & P_{22} \cdots & P_{2 n} \\
P_{31} & P_{32} \cdots & P_{3 n}
\end{array}\right|
$$

Each transition probability value in this matrix denotes the persistence/conversion probability of a particular land-use type (rows: land-use type of a previous time point) to another land-use type (columns: land-use type of a later time point), with the assumption of there being constant land-use conversion probabilities [13,51]. The principal diagonal values represent the probabilities of LUC continuity: the likelihood of the specified land-use class remaining unchanged while the off-diagonal values show the land use conversions across land-use classes [14,26,29].

\subsubsection{Integrated CA-MC Urban Growth Model}

Both CA and MC models have their limitations, i.e., the inability to empirically describe the LUCs (CA) and the geographical lack of specificity when describing changes (MC), respectively [24,52]. An integrated CA-MC, therefore, increases both models' capability by capitalizing on their respective qualities [4,31]: it combines the neighborhood effects of the CA and the historical transition probability effects of the MC, thus giving a more comprehensive prediction of the LUCs $[14,17,51]$. Unlike other models, this has the advantages of incorporating both time and spatial variability, while at the same time recognizing some of the major biophysical and socio-economic drivers underlying LUC $[8,14]$. In identifying these potential factors, we use an AHP technique that allows the incorporation of the insights and decisions of experts [53,54].

\subsubsection{Analytical Hierarchy Process}

AHP is a multi-criteria evaluation tool used to determine the relative weights of factors using pairwise comparisons $[16,28,55]$. In our research, we employed Saaty's AHP technique, which involves a 9-relative-point scale in which larger AHP values represent higher preferences of the expert towards one of the contending factors (Table 3) [56]. An AHP value of 1 denotes that the expert judges the two urban expansion factors as equally important, whereas 9 represents the absolute preference of the expert for one factor over the other in determining the nature of LUC.

Table 3. AHP point scales.

\begin{tabular}{ccc}
\hline Value & Definition & Explanation \\
\hline 1 & Equally preferred & Two factors are equally affecting the objective \\
3 & Weak preference & One of the two factors is slightly favored \\
5 & Strong preference & One of the two factors is strongly favored \\
7 & Very strong preference & One of the two factors is very strongly favored \\
9 & Absolute preference & One of the two factors is absolutely favored \\
$2,4,6,8$ & Intermediate preferences between & The experts' transitional judgments of between \\
& the two neighboring values & adjacent preferences. \\
\hline
\end{tabular}

In our study, the competing urban expansion factors are slope, elevation, distance to major roads, distance to Central Business District (CBD), and distance to water bodies. The study area is mapped against each of these factors (Figure 3). The city is at the intersection of three major roads (Addis Ababa to Gondar, crossing the city from southwest to northeast; Bahir Dar to Tis-Abay, running from the city 
center in a southerly direction; and Bahir Dar airport to the city center, from a western direction; see Figure 3A) and has two major CBDs: the Abay and Tana market (in the west), and Abay-Mado market (in the east), which act as the city's two main commercial centers (see Figure 3B).
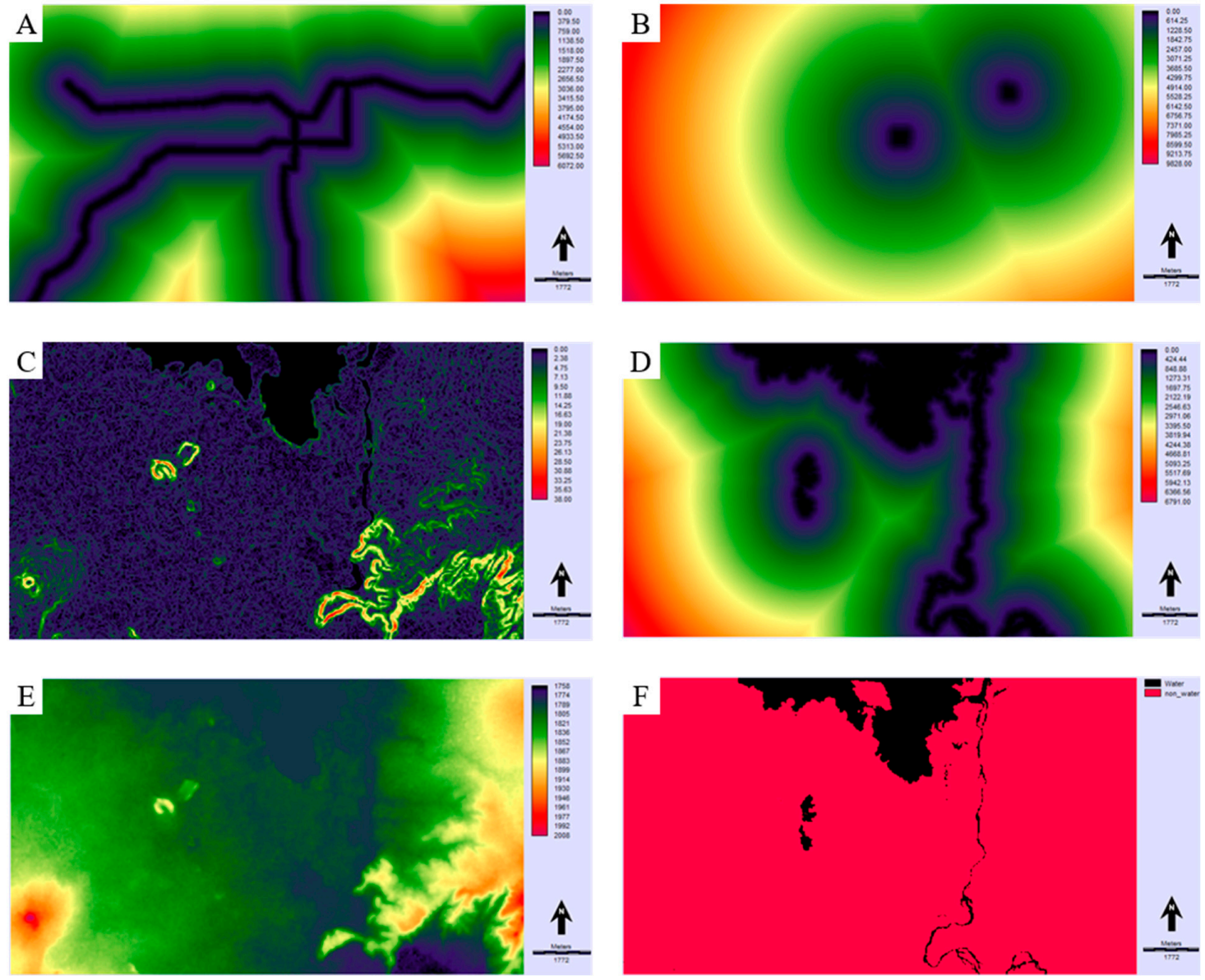

Figure 3. Factors and constraint layer of urban expansion. (A,B,D) show the distance to the major road network, $\mathrm{CBD}$, and waterbodies respectively (where distances increase from black to red), using Euclidean distance. (C,E) show slope (where slope increase from black to red) and elevation (altitude increases from black to red), respectively. (F) shows water bodies as a constraint layer (black represents water body; red, non-waterbody).

In November 2018, we presented a pairwise comparison questionnaire to a total of 10 local experts working in the field of urban planning, surveying, and geography. These experts are affiliated with the ANRS Bureau of Urban Development, Housing and Construction, the Amhara Urban Planning Institute, the Bahir Dar City Administration, and Bahir Dar University. Using the responses of these experts in the form of an AHP matrix, we computed the expansion factor weights using the multi-criteria evaluation (MCE) module in IDRISI. According to Saaty [56], the relative weights set by the experts have to be consistent, which can be measured using a consistency ratio (CR). We computed the $\mathrm{CR}$ as the ratio between the consistency index (CI) and the random index (RI) [54,56]. In an $n \times n$ AHP matrix, RI is the average consistency index based on the given matrix order by Saaty [56].

$$
\begin{gathered}
\mathrm{CR}=\mathrm{CI} / \mathrm{RI} \\
\mathrm{CI}=\left(\lambda_{\max }-\mathrm{n}\right) /(\mathrm{n}-1)
\end{gathered}
$$

where $\lambda_{\max }$ is the principal eigenvalue of the AHP pairwise matrix. For reliable expert judgment, the CR value should be less than $0.1[12,56]$. 
Based on a survey of the literature, the selected input factors (Figure 3) were standardized using the sigmoid, J-shaped, and linear fuzzy membership functions in IDRISI [4,24,30,57,58]. We opted for a monotonically decreasing J-shaped membership function for distance to major roads with control points of $300 \mathrm{~m}$ and $2 \mathrm{~km}$. Based on the literature [24,58,59] and personal observation of trends in the area, a distance of up to $300 \mathrm{~m}$ was considered as highly suitable, after which the suitability decreases between $300 \mathrm{~m}$ and $2 \mathrm{~km}$ to become unsuitable for urbanization after $2 \mathrm{~km}$. Similarly, the $0 \mathrm{~m}$ and $3 \mathrm{~km}$ control points were used in monotonically decreasing linear function for the distance to the CBD factor. Finally, a monotonically decreasing sigmoid function was used for rescaling the slope factor with the control points of $0 \%$ and $15 \%$, elevation with 1850 and $1900 \mathrm{~m}$, and the distance to water bodies with $500 \mathrm{~m}$ and $3 \mathrm{~km}$. For example, a slope of $0 \%$ represents a high suitability, after which suitability decreases to $15 \%$, while beyond $15 \%$, it is considered to be unsuitable.

\subsection{Model Calibration and Validation}

Model implementation and calibration is a critical step when applying a CA-MC model [2]. The integrated CA-MC model in this research draws on the computed transition probability matrix and suitability map of the area. Here, we employed the classified land use maps of 1991, 2002, 2011, and 2018 to compute the possible likelihood of each cell through time. Thus cells are arranged in descending order to various states (land-use classes) based on the transition rules in each iteration of the CA-MC module in IDRISI [10]: one iteration is assumed to be equal to one year. In this study, the suitability map of the area is derived from using biophysical and socioeconomic driving forces and a constraint layer $[2,60,61]$. This urban suitability map output from IDRISI is given by standardized values between 0 and 255, where 0 signifies no suitability and 255 is highly suitable for a specific land-use class $[4,24,26]$ using the combination of transition factors and the constraint layer (Figure 3). The model calibration was conducted in 2018. Subsequently, we projected the urban (built-up) expansion impact on LUCs for the coming years.

In this study, the CA-MC model projection is validated using the kappa index of agreement (KIA) technique by fitting the actual onto the simulated land use maps of the area $[13,19,55,62]$. The kappa (K) value indicates the model's goodness of fit, comparing the observed agreement and expected agreement by chance between the two land use maps, and is computed as

$$
\mathrm{K}=\left(\mathrm{P}_{0}-\mathrm{P}_{\mathrm{e}}\right) /\left(1-\mathrm{P}_{\mathrm{e}}\right)
$$

where $P_{0}$ is the observed agreement, and $P_{e}$ the expected agreement by chance. The value of $K$ ranges from -1 to 1 . Negative values of $K$ represent disagreement between the observed and expected agreements, whereas values greater than 0 represent agreements [63-65].

The K metric has both strengths and limitations for validating a CA-MC model. Its high dependency on land use persistence, the inability to recognize new developments, and uniform assumptions of spatiotemporal urban growth are among the limitations $[65,66]$. Despite these weaknesses, K metrics are still the most commonly used technique for validating the CA-MC model $[2,58]$.

\section{Results}

\subsection{Classification Accuracy}

We found an overall classification accuracy of 0.89 , which is satisfactory given that an accuracy of 0.85 is considered to be a minimum criterion $[38,67,68]$. The different land-use classes have the following classification accuracies: water (0.96), farmland (0.93), built-up (0.87), rangeland (0.77), and vegetation (0.90), with the slightly higher classification errors for rangeland and built-up areas likely being due to the color reflection resemblance of the roofs of traditional buildings and paved ways in the study area, which could mistakenly be classified across other land uses. 


\subsection{Temporal Land-Use Changes}

Corroborating the rationale for this research, it can be seen that built-up areas between 1991 and 2018 have been steadily expanding over time (Table 4). This expansion mainly results in a sharp and accelerating decline in farmland: 603 (1991-2002), 1204 (2002-2011), and 1598 ha (2011-2018). In other words, in 1991, there was more than four times as much farmland as there was built-up areas in the study area, but by 2018, the built-up area had become almost twice as large as the share of farmland. The built-up expansion has, above all, been pronounced in erstwhile peripheral areas (Figure 4). As a result, about 1635 hectares of built-up area has been added to the southern, southwestern, and northeastern fringes of the city. Overall, in the past 27 years, about 3405 hectares of farmland have been converted into other land-use classes, mainly into built-up areas.

Table 4. Land-use changes between 1991 and 2018 (in hectare).

\begin{tabular}{ccccc}
\hline \multirow{2}{*}{ Category } & \multicolumn{5}{c}{ Year } \\
\cline { 2 - 5 } & $\mathbf{1 9 9 1}$ & $\mathbf{2 0 0 2}$ & $\mathbf{2 0 1 1}$ & $\mathbf{2 0 1 8}$ \\
\hline Waterbody & 1139 & 1059 & 1032 & 1079 \\
Farmland & 5695 & 5092 & 3888 & 2290 \\
Built-up & 1246 & 2708 & 3202 & 4343 \\
Rangeland & 3567 & 3385 & 3462 & 4024 \\
Forest (vegetation) & 2948 & 2350 & 3010 & 2858 \\
\hline
\end{tabular}
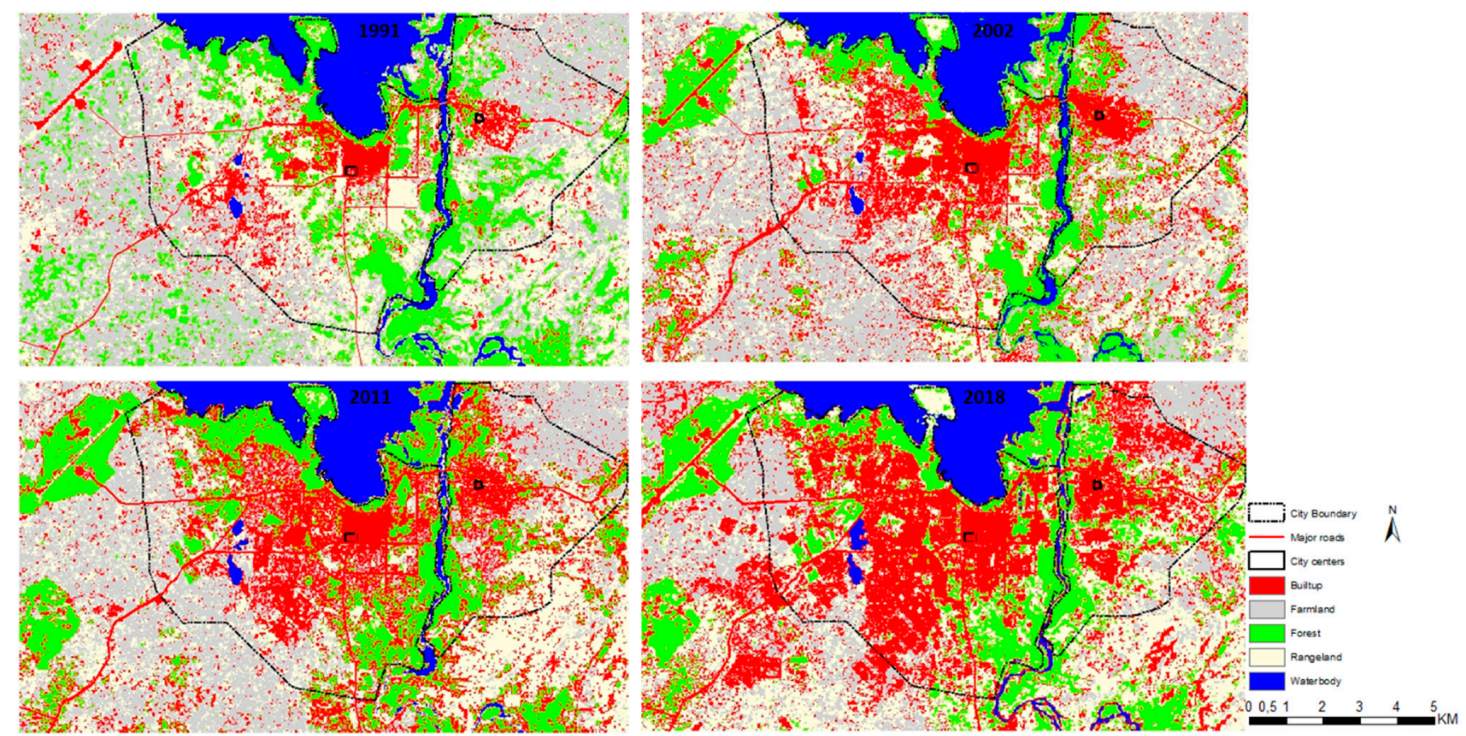

Figure 4. Land-use maps between 1991 and 2018.

\subsection{Factors of Urban Expansion}

Based on the experts' responses, we assume that geographies of urban expansion are mainly driven by distance to major roads and the $\mathrm{CBD}$, followed by the physical factor of slope. The AHP relative weights for these expansion factors are distance to major roads $(0.40)$, distance to CBD, $(0.26)$, slope (0.16), distance to water bodies (0.11), and elevation (0.05). We obtained a consistency ratio of 0.03 , which is well below the maximum acceptable value by Saaty [56], indicating that the experts' judgments were broadly consistent in the identification process.

\subsection{Markov Chain Transition Probabilities}

Table 5 shows the Markov transition probability matrix computed based on two previous land use maps of the area [13,51]. For example, between 2002 and 2011, more than half of the farmland 
was changed into built-up areas (17.3\%) and rangeland (34.2\%). In the entire period (1991-2018), only $23.2 \%$ of farmland remained unconverted. During this period, 30.3\% farmland, 38.4\% rangeland, and $24.7 \%$ of the forest were shifted to built-up areas as a result of rapid urbanization in the area (Figure 4 ). The transition probabilities derived from this are then used to compute the likely changes for future LUCs: the 2002-2011 probability matrix was used to calculate the LUCs for 2018, 2011-2018 for 2025, 2002-2018 for 2034, and 1991-2018 for 2045.

Table 5. Markov transition probabilities for different periods.

\begin{tabular}{|c|c|c|c|c|c|c|}
\hline Period & Category & Waterbody & Farmland & Built-up & Rangeland & Forest \\
\hline \multirow{5}{*}{$\begin{array}{c}2002-2011 \\
\text { for } 2018\end{array}$} & Waterbody & 0.8054 & 0 & 0.0257 & 0.1463 & 0.0225 \\
\hline & Farmland & 0.0008 & 0.4197 & 0.1731 & 0.3415 & 0.0649 \\
\hline & Built-up & 0 & 0.2018 & 0.4283 & 0.2216 & 0.1483 \\
\hline & Rangeland & 0.0017 & 0.3267 & 0.1994 & 0.331 & 0.1411 \\
\hline & Forest & 0.0155 & 0.0095 & 0.2516 & 0.0709 & 0.6525 \\
\hline \multirow{5}{*}{$\begin{array}{l}2011-2018 \\
\text { for } 2025\end{array}$} & Waterbody & 0.7935 & 0 & 0.0945 & 0.043 & 0.069 \\
\hline & Farmland & 0.0004 & 0.3198 & 0.3635 & 0.2947 & 0.0216 \\
\hline & Built-up & 0.0075 & 0.0559 & 0.4502 & 0.2918 & 0.1945 \\
\hline & Rangeland & 0.0198 & 0.2186 & 0.3215 & 0.3957 & 0.0443 \\
\hline & Forest & 0.0147 & 0.0021 & 0.149 & 0.2441 & 0.5901 \\
\hline \multirow{5}{*}{$\begin{array}{c}2002-2018 \\
\text { for } 2034\end{array}$} & Waterbody & 0.7737 & 0 & 0.0974 & 0.0394 & 0.0895 \\
\hline & Farmland & 0.0034 & 0.2486 & 0.3273 & 0.3291 & 0.0917 \\
\hline & Built-up & 0.0018 & 0.0822 & 0.4592 & 0.2857 & 0.1711 \\
\hline & Rangeland & 0.003 & 0.1971 & 0.302 & 0.3443 & 0.1536 \\
\hline & Forest & 0.0459 & 0.0032 & 0.1855 & 0.2172 & 0.5482 \\
\hline \multirow{5}{*}{$\begin{array}{c}1991-2018 \\
\text { for } 2045\end{array}$} & Waterbody & 0.7454 & 0 & 0.0992 & 0.0423 & 0.1131 \\
\hline & Farmland & 0.0006 & 0.2319 & 0.3032 & 0.3149 & 0.1497 \\
\hline & Built-up & 0.0155 & 0.1544 & 0.5034 & 0.2132 & 0.1135 \\
\hline & Rangeland & 0.0073 & 0.1545 & 0.3839 & 0.2951 & 0.1592 \\
\hline & Forest & 0.0142 & 0.0257 & 0.2474 & 0.3242 & 0.3884 \\
\hline
\end{tabular}

\subsection{Integrated $C A-M C$ Model Implementation and Validation}

The combination of a suitability map, the recent land-use map, and the transition probabilities implies that, above all, areas with flatter slopes and medium altitudes that are relatively near to major roads, the $\mathrm{CBD}$, or water bodies, are considered to be suitable for urban expansion. At the same time, however, the water bodies (the lake and the river) are an obvious constraint for this expansion (Figure 3). Based on this, we projected the expansion and LUCs for 2018, 2025, 2034, and 2045, respectively (Figure 5).

The projected 2018 LUC map, in turn, is used for validating the model performances. By comparing the actual and projected land use maps of 2018, we found a kappa value of 0.42 . This Kappa value indicates that the model accuracy is moderate yet acceptable for projecting future LUCs as the observed agreement using the model exceeds the expected agreement by chance $[23,62,63]$.

The projected built-up expansion will occur in different directions, with varying extents, and replacing different types of land use in the years to come (Figure 5). For example, the built environment LUC between 2018 and 2025 is projected to mainly take place at the urban fringes, especially in the southwestern and northeastern parts of the city-sprawl will thus continue to be a major reality in this period if recent trends, dynamics, and processes persist. In this period, most of the conversion into built-up areas will be from farmland and rangeland; meanwhile, the projected LUCs between 2025 and 2034 results mainly from a reduction in rangeland and forest. During this period, this built-up expansion is projected to occur mainly within the existing city boundaries. Finally, the built-up expansion between 2034 and 2045 is even more clearly scheduled to take place within the city boundaries, pointing to overall patterns of densification rather than sprawl. In this period, the 
projected built-up expansion is mainly occurring through the conversion of forestland and rangeland into built-up areas.

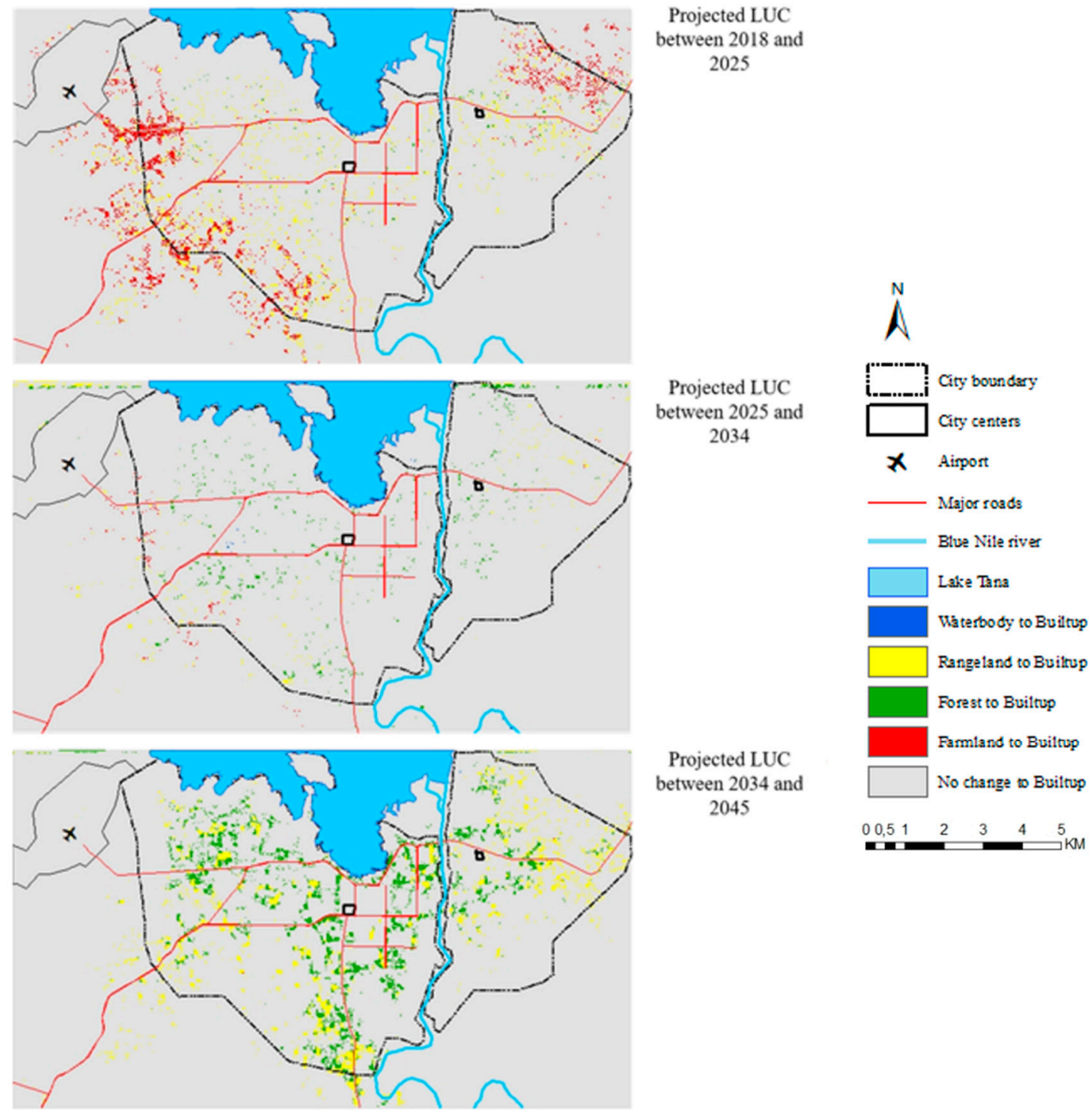

Figure 5. Predicted built environment expansion maps for 2025, 2034, and 2045.

Overall, then, the built-up area will further increase from its current share of $30 \%$ to $36 \%$ in 2045 (a 930-hectare increase) in the southern, southwestern and northeastern parts of the city (Figure 5). More than half of the expansion will either follow the major roads or concentrate close to the two major market centers. Alongside this, there will be a reduction in rangeland, farmland, and forest (Table 6).

Table 6. The predicted LUC between 2025 and 2045.

\begin{tabular}{ccccccc}
\hline \multirow{2}{*}{ Land-Use Type } & \multicolumn{2}{c}{ Predicted 2025 } & \multicolumn{2}{c}{ Predicted 2034 } & \multicolumn{2}{c}{ Predicted 2045 } \\
& Area (ha) & $\mathbf{\%}$ & Area (ha) & $\mathbf{\%}$ & Area (ha) & $\mathbf{\%}$ \\
\hline Waterbody & 1034 & 7 & 1064 & 7 & 1072 & 7 \\
Farmland & 1739 & 12 & 1675 & 11 & 1869 & 12 \\
Built-up & 4846 & 33 & 4670 & 32 & 5276 & 36 \\
Rangeland & 4226 & 29 & 4009 & 27 & 3772 & 26 \\
Forest & 2752 & 19 & 3178 & 23 & 2608 & 19 \\
\hline
\end{tabular}




\section{Discussion}

In this study, drawing on an integrated CA-MC model, we mapped the major conversion of other land uses into a built environment as a result of the uncontrolled urban expansion in Bahir Dar city. During the last three decades, the fourfold population increase in the city has been matched by a quadrupling of built-up expansion and LUCs [37] (Table 4). According to Adam [69], this expansion has taken the shape of both formal and informal settlements in replacing farmland, rangeland, and forests. Formal settlement programs include the government's land lease and condominium housing programs, and the gradual distribution of subsidized or free land for house construction. For example, in 2013/2014, Bahir Dar city administration distributed about 65 hectares of land to 4345 households organized in housing associations, mainly by land expropriation from neighborhood farmers. In addition, informal settlement expansion has also played a major role in LUCs in the area, referring to the construction of houses on illegally occupied land, or houses that do not comply with the city land-use planning and building permits. About $30 \%$ of the total housing stock in Bahir Dar has been reported as being informal, and this figure has likely grown in recent years [69].

In recent years, this unplanned urban sprawl and the associated LUCs have faced resistance from local farmers and landowners due to inadequate compensation of land expropriation [20,70]. For example, farmers living in neighboring small rural areas (Kebele) such as Yibab, Yinesa Sositu, and Robit are resisting the formal settlement expansion programs by the city administration. This creates an inability on the part of the local government to provide housing land for the existing waiting lists of housing associations. In addition, in reality, vegetation cover is also deteriorating as the built environment stretches into the rural areas [20,71]. For example, the forest cover on Dibanqie hill (to the west), and Bezawit hilltop (to the east) has been depleting over the last decades.

Similar to many cities in developing countries, urban sprawl processes in Bahir Dar will likely continue due to both the natural population growth and the rural to urban migration $[20,72,73]$. In spite of this, in due time, because of the assumed socio-economic and biophysical factors in an integrated CA-MC model, we predict there will be urban densification in Bahir Dar (Figure 5). This process implies rapid urbanization in developing countries in general, and Bahir Dar city, in particular, does not equate with never-ending sprawl as, for example, accessibility to infrastructure is also a major determinant underlying urbanization. As far as socioeconomic and biophysical factors of urbanization are concerned, the factors such as distance to road, distance to CBD, and slope can significantly affect the shape and size of the city expansion $[74,75]$. Thus, the development of key infrastructure, including road construction and the establishment of sub-centers, can guide future built-up expansion [76].

The implementation of appropriate urban planning and land use management is vital to curb the excessive sprawling into the neighboring rural communities on the one hand and overcrowding in the core city areas on the other hand. To this end, urban stakeholders, especially city administrators and urban planners, can consider implementing effective urban planning strategies through the establishment of new subcenters and the development of road infrastructure [33,72,77-79]. Thus, a future study could assess the role of various urban decision-makers in the land-use change processes of urban areas. By doing so, the findings would be useful as the inputs for urban planners and other stakeholders to understand the linkage and interaction of built-up expansion and the nearby areas.

Both the research findings in this study and related previous studies tried to show the usefulness of the application of the CA-MC model to figure out factors and trends of urban expansion and its impact on the land-use changes of a particular area $[4,24,31,55]$. Indeed, the model identified the role of biophysical and socioeconomic variables in predicting future urbanization processes. Despite the strength of this model, further studies are needed to include various non-quantitative and spatially heterogeneous variables of urbanization and land-use changes using social-ecological modeling such as agent-based models [43,80-82]. 


\section{Conclusions}

In this paper, we developed a model predicting the spatiotemporal dynamics of LUC in and around Bahir Dar, Ethiopia. We combined a CA-MC model with the AHP technique in order to introduce expert opinions for deciding on the potential factors of urban expansion in the area. Based on the historical LUC from 1991 to 2018, the study has attempted to detect, simulate and predict the future expansion trends up to 2045, with a specific empirical focus on changes in the built-up area. This has, in turn, been validated by comparing the actual and projected 2018 land use maps.

The encroachment of farmland has been drastic in these past decades: its share in the total research area has been reduced from $39 \%$ to $15 \%$. The current land-use change probability matrix in Table 5 suggests that this decline will continue, albeit at a slower pace. If the model predictions hold (i.e., the transition factors and the historical MC probability matrix producing valuable insight), in the coming three decades, 15.6 ha farmland, 9.4 ha rangeland, and 3.9 ha forest will annually be converted into built-up areas. Distance to major roads and closeness to the city centers will direct this projected expansion, resulting in expansion and densification in the southern, southwestern and northeastern parts of the city. Hence, future infrastructural developments and establishment of subcenters are critical in accommodating the growing population and achieving sustainable urbanization.

One key contribution of our paper has been that it evaluates LUC as a result of rapid urbanization by combining the biophysical and socioeconomic variables: distance to road, distance to the CBD, and distance to water bodies, slope, and elevation. This spatiotemporally explicit CA-MC model integrates the qualities of the two individual models and experts' judgment. Indeed, unlike other models, it measures both the scope and the geographical specifics of expansion. Its result can be used for improving land use management and city planning as it presents the factors and the trends of urban expansions in light of ongoing LUCs. Thus, urban stakeholders, especially local authorities and planners, should consider the influence of these factors on the urban expansion, i.e., road networks and distance to the city center to be dominant drivers in the area. However, despite the robustness of the CA-MC model, further studies are needed to identify the role of various urban agents and explore the non-quantitative and non-spatial governing processes of land-use changes.

Author Contributions: Conceptualization, M.B.F., B.D., and A.S.M.; Data curation, M.B.F.; Formal analysis, M.B.F., B.D., and A.S.M; Funding acquisition, B.D., A.S.M., S.V.P., E.A., and J.N; Investigation, M.B.F.; Methodology, M.B.F., and B.D.; Project administration, S.V.P., E.A., and J.N.; Resources, M.B.F., B.D., and A.S.M.; Software, M.B.F.; Supervision, B.D., and A.S.M; Validation, M.B.F.; Visualization, M.B.F., and B.D; Writing-original draft, M.B.F., and B.D.; Writing-review and editing, M.B.F., B.D., A.S.M., S.V.P., E.A., and J.N. All authors have read and agreed to the published version of the manuscript.

Funding: The authors would like to thank the VLIR-UOS project for funding this research through Bahir Dar University-Institutional University Cooperation (BDU-IUC) program.

Acknowledgments: The authors acknowledge the local experts and data collector participants (Ermiyas Shitahun, Melak Tsehay, and Yalembirhan Mebratu) for their commitment.

Conflicts of Interest: The authors declare no conflict of interest. The funders had no role in the design of the study; in the collection, analyses, or interpretation of data; in the writing of the manuscript, or in the decision to publish the results.

\section{References}

1. Deep, S.; Saklani, A. Urban sprawl modeling using cellular automata. Egypt. J. Remote Sens. Space Sci. 2014, 17, 179-187. [CrossRef]

2. Tang, J.; Di, L. Past and Future Trajectories of Farmland Loss Due to Rapid Urbanization Using Landsat Imagery and the Markov-CA Model: A Case Study of Delhi, India. Remote Sens. 2019, 11, 180. [CrossRef]

3. Xu, G.; Dong, T.; Cobbinah, P.B.; Jiao, L.; Sumari, N.S.; Chai, B.; Liu, Y. Urban expansion and form changes across African cities with a global outlook: Spatiotemporal analysis of urban land densities. J. Clean. Prod. 2019, 224, 802-810. [CrossRef] 
4. Arsanjani, J.J.; Helbich, M.; Kainz, W.; Boloorani, A.D. Integration of logistic regression, Markov chain and cellular automata models to simulate urban expansion. Int. J. Appl. Earth Obs. Geoinf. 2012, 21, 265-275. [CrossRef]

5. Bren d'Amour, C.; Reitsma, F.; Baiocchi, G.; Barthel, S.; Güneralp, B.; Erb, K.-H.; Haberl, H.; Creutzig, F.; Seto, K.C. Future urban land expansion and implications for global croplands. Proc. Natl. Acad. Sci. USA 2017, 114, 8939-8944. [CrossRef]

6. United Nations World Urbanization Prospects: The 2011 Revision; Desa: New York, NY, USA, 2012; p. 318.

7. Güneralp, B.; Lwasa, S.; Masundire, H.; Parnell, S.; Seto, K.C.; Parnell, S.; Masundire, H.; Güneralp, B.; Lwasa, S. Urbanization in Africa: Challenges and opportunities for conservation. Environ. Res. Lett. 2017, 13, 015002. [CrossRef]

8. Alqurashi, A.F.; Kumar, L.; Sinha, P. Urban land cover change modelling using time-series satellite images: A case study of urban growth in five cities of Saudi Arabia. Remote Sens. 2016, 8, 838. [CrossRef]

9. Schweitzer, F. A growing urban problem. Nature 2006, 441, 815. [CrossRef]

10. Barredo, J.I.; Demicheli, L. Urban sustainability in developing countries' megacities: Modelling and predicting future urban growth in Lagos. Cities 2003, 20, 297-310. [CrossRef]

11. Myers, G. African Cities: Alternative Visions of Urban Theory and Practice; Zed Books Ltd.: London, UK, 2011; ISBN 1780321333.

12. Bisello, A.; Vettorato, D.; Stephens, R.; Elisei, P. Smart and Sustainable Planning for Cities and Regions; Springer Nature: Heidelberg, Germany, 2017; ISBN 9783319448992.

13. Mosammam, H.M.; Nia, J.T.; Khani, H.; Teymouri, A.; Kazemi, M. Monitoring land use change and measuring urban sprawl based on its spatial forms: The case of Qom city. Egypt. J. Remote Sens. Space Sci. 2017, 20, 103-116.

14. Rimal, B.; Zhang, L.; Keshtkar, H.; Wang, N.; Lin, Y. Monitoring and Modeling of Spatiotemporal Urban Expansion and Land-Use/Land-Cover Change Using Integrated Markov Chain Cellular Automata Model. ISPRS Int. J. Geo-Inf. 2017, 6, 288. [CrossRef]

15. Gharbia, S.S.; Alfatah, S.A.; Gill, L.; Johnston, P.; Pilla, F. Land use scenarios and projections simulation using an integrated GIS cellular automata algorithms. Model. Earth Syst. Environ. 2016, 2, 151. [CrossRef]

16. Halmy, M.W.A.; Gessler, P.E.; Hicke, J.A.; Salem, B.B. Land use/land cover change detection and prediction in the north-western coastal desert of Egypt using Markov-CA. Appl. Geogr. 2015, 63, 101-112. [CrossRef]

17. Naghibi, F.; Delavar, M.R.; Pijanowski, B. Urban growth modeling using cellular automata with multi-temporal remote sensing images calibrated by the artificial bee colony optimization algorithm. Sensors (Switzerland) 2016, 16, 2122. [CrossRef]

18. Nguyen, T.A.; Le, P.M.T.; Pham, T.M.; Hoang, H.T.T.; Nguyen, M.Q.; Ta, H.Q.; Phung, H.T.M.; Le, H.T.T.; Hens, L. Toward a sustainable city of tomorrow: A hybrid Markov-Cellular Automata modeling for urban landscape evolution in the Hanoi city (Vietnam) during 1990-2030. Environ. Dev. Sustain. 2019, 21, 429-446. [CrossRef]

19. Berberoğlu, S.; Akin, A.; Clarke, K.C. Cellular automata modeling approaches to forecast urban growth for adana, Turkey: A comparative approach. Landsc. Urban Plan. 2016, 153, 11-27. [CrossRef]

20. Haregeweyn, N.; Fikadu, G.; Tsunekawa, A.; Tsubo, M.; Meshesha, D.T. The dynamics of urban expansion and its impacts on land use/land cover change and small-scale farmers living near the urban fringe: A case study of Bahir Dar, Ethiopia. Landsc. Urban Plan. 2012, 106, 149-157. [CrossRef]

21. Singh, S.K.; Laari, P.B.; Mustak, S.; Srivastava, P.K.; Szabó, S. Modelling of land use land cover change using earth observation data-sets of Tons River Basin, Madhya Pradesh, India. Geocarto Int. 2017, 6049, 1-21. [CrossRef]

22. Jafari, M.; Majedi, H.; Monavari, S.; Alesheikh, A.; Kheirkhah Zarkesh, M. Dynamic Simulation of Urban Expansion Based on Cellular Automata and Logistic Regression Model: Case Study of the Hyrcanian Region of Iran. Sustainability 2016, 8, 810. [CrossRef]

23. Amini Parsa, V.; Salehi, E. Spatio-temporal analysis and simulation pattern of land use/cover changes, case study: Naghadeh, Iran. J. Urban Manag. 2016, 5, 43-51. [CrossRef]

24. Shafizadeh Moghadam, H.; Helbich, M. Spatiotemporal urbanization processes in the megacity of Mumbai, India: A Markov chains-cellular automata urban growth model. Appl. Geogr. 2013, 40, 140-149. [CrossRef] 
25. Jokar Arsanjani, J.; Fibæk, C.S.; Vaz, E. Development of a cellular automata model using open source technologies for monitoring urbanisation in the global south: The case of Maputo, Mozambique. Habitat Int. 2018, 71, 38-48. [CrossRef]

26. Kamusoko, C.; Aniya, M.; Adi, B.; Manjoro, M. Rural sustainability under threat in Zimbabwe-Simulation of future land use/cover changes in the Bindura district based on the Markov-cellular automata model. Appl. Geogr. 2009, 29, 435-447. [CrossRef]

27. Fu, X.; Wang, X.; Yang, Y.J. Deriving suitability factors for CA-Markov land use simulation model based on local historical data. J. Environ. Manag. 2018, 206, 10-19. [CrossRef] [PubMed]

28. Zhang, Q.; Ban, Y.; Liu, J.; Hu, Y. Simulation and analysis of urban growth scenarios for the Greater Shanghai Area, China. Comput. Environ. Urban Syst. 2011, 35, 126-139. [CrossRef]

29. Guan, D.; Li, H.; Inohae, T.; Su, W.; Nagaie, T.; Hokao, K. Modeling urban land use change by the integration of cellular automaton and Markov model. Ecol. Model. 2011, 222, 3761-3772. [CrossRef]

30. Lu, Q.; Chang, N.B.; Joyce, J.; Chen, A.S.; Savic, D.A.; Djordjevic, S.; Fu, G. Exploring the potential climate change impact on urban growth in London by a cellular automata-based Markov chain model. Comput. Environ. Urban Syst. 2018, 68, 121-132. [CrossRef]

31. Aburas, M.M.; Ho, Y.M.; Ramli, M.F.; Ash'aari, Z.H. The simulation and prediction of spatio-temporal urban growth trends using cellular automata models: A review. Int. J. Appl. Earth Obs. Geoinf. 2016, 52, 380-389. [CrossRef]

32. Mundia, C.N.; Murayama, Y. Modeling Spatial Processes of Urban Growth in African Cities: A Case Study of Nairobi City. Urban Geogr. 2010, 31, 259-272. [CrossRef]

33. Agyemang, F.S.K.K.; Silva, E. Simulating the urban growth of a predominantly informal Ghanaian city-region with a cellular automata model: Implications for urban planning and policy. Appl. Geogr. 2019, 105, 15-24. [CrossRef]

34. UN-Habitat. Urbanization and Development: Emerging Futures; UN-Habitat: Nairobi, Kenya, 2016; ISBN 9789211333954.

35. United Nations. World Population Prospects: The 2012 Revision. Econ. Soc. Aff. 2013, 27, 800-812.

36. Lambin, E.F.; Meyfroidt, P. Global land use change, economic globalization, and the looming land scarcity. Proc. Natl. Acad. Sci. USA 2011, 108, 3465-3472. [CrossRef] [PubMed]

37. Central Statistical Agency. Population Projection of Ethiopia for All Regions At Wereda Level from 2014-2017. J. Ethnobiol. Ethnomed. 2013, 3, 28.

38. Anderson, J.R. A Land Use and Land Cover Classification System for Use with Remote Sensor Data; USGS: Reston, VA, USA, 1978; p. 37.

39. Fathizad, H.; Rostami, N.; Faramarzi, M. Detection and prediction of land cover changes using Markov chain model in semi-arid rangeland in western Iran. Environ. Monit. Assess. 2015, 187, 629. [CrossRef] [PubMed]

40. Cobbinah, P.B.; Erdiaw-Kwasie, M.O.; Amoateng, P. Africa's urbanisation: Implications for sustainable development. Cities 2015, 47, 62-72. [CrossRef]

41. Batty, M. Cities and Complexity: Understanding Cities with Cellular Automata, Agent-Based Models, and Fractals; The MIT Press: Cambridge, MA, USA, 2007; ISBN 0262524791.

42. Hu, Z.; Lo, C.P. Modeling urban growth in Atlanta using logistic regression. Comput. Environ. Urban Syst. 2007, 31, 667-688. [CrossRef]

43. Santé, I.; García, A.M.; Miranda, D.; Crecente, R. Cellular automata models for the simulation of real-world urban processes: A review and analysis. Landsc. Urban Plan. 2010, 96, 108-122. [CrossRef]

44. Wahyudi, A.; Liu, Y. Cellular automata for urban growth modelling. Int. Rev. Spat. Plan. Sustain. Dev. 2016, 4, 60-75. [CrossRef]

45. Benenson, I.; Torrens, P.M. Geographic Automata Systems: A New Paradigm for Integrating GIS and Geographic Simulation. GeoComputation 2003, 2003, 24-30.

46. White, R.; Engelen, G. Cellular Automata and Fractal Urban Form: A Cellular Modelling Approach to the Evolution of Urban Land-Use Patterns. Environ. Plan. A Econ. Space 1993, 25, 1175-1199. [CrossRef]

47. Ghosh, P.; Mukhopadhyay, A.; Chanda, A.; Mondal, P.; Akhand, A.; Mukherjee, S.; Nayak, S.K.K.; Ghosh, S.; Mitra, D.; Ghosh, T.; et al. Application of Cellular automata and Markov-chain model in geospatial environmental modeling-A review. Remote Sens. Appl. Soc. Environ. 2017, 5, 64-77. [CrossRef]

48. White, R.; Engelen, G.; Uljee, I. The use of constrained cellular automata for high-resolution modelling of urban land-use dynamics. Environ. Plan. B Plan. Des. 1997, 24, 323-343. [CrossRef] 
49. White, R.; Engelen, G. High-resolution integrated modelling of the spatial dynamics of urban and regional systems. Comput. Environ. Urban Syst. 2000, 24, 383-400. [CrossRef]

50. Batty, M.; Couclelis, H.; Eichen, M. Urban Systems as Cellular Automata. Environ. Plan. B Plan. Des. 1997, 24, 159-164. [CrossRef]

51. Mondal, M.S.; Sharma, N.; Kappas, M.; Garg, P.K. Modeling of spatio-temporal dynamics of land use and land cover in a part of Brahmaputra River basin using Geoinformatic techniques. Geocarto Int. 2013, 28, 632-656. [CrossRef]

52. Hamdy, O.; Zhao, S.; Osman, T.; Salheen, M.; Eid, Y. Applying a Hybrid Model of Markov Chain and Logistic Regression to Identify Future Urban Sprawl in Abouelreesh, Aswan: A Case Study. Geosciences 2016, 6, 43. [CrossRef]

53. Liu, Y.; He, Q.; Tan, R.; Liu, Y.; Yin, C. Modeling different urban growth patterns based on the evolution of urban form: A case study from Huangpi, Central China. Appl. Geogr. 2016, 66, 109-118. [CrossRef]

54. Park, S.; Jeon, S.; Kim, S.; Choi, C. Landscape and Urban Planning Prediction and comparison of urban growth by land suitability index mapping using GIS and RS in South Korea. Landsc. Urban Plan. 2011, 99, 104-114. [CrossRef]

55. Aburas, M.M.; Ho, Y.M.; Ramli, M.F.; Ash'aari, Z.H. Improving the capability of an integrated CA-Markov model to simulate spatio-temporal urban growth trends using an Analytical Hierarchy Process and Frequency Ratio. Int. J. Appl. Earth Obs. Geoinf. 2017, 59, 65-78. [CrossRef]

56. Saaty, T.L. A scaling method for priorities in hierarchical structures. J. Math. Psychol. 1977, 15, $234-281$. [CrossRef]

57. Barredo, J.I.; Demicheli, L.; Lavalle, C.; Kasanko, M.; McCormick, N. Modelling future urban scenarios in developing countries: An application case study in Lagos, Nigeria. Environ. Plan. B Plan. Des. 2004, 31, 65-84. [CrossRef]

58. Ozturk, D. Urban growth simulation of Atakum (Samsun, Turkey) using cellular automata-Markov chain and Multi-layer Perceptron-Markov chain models. Remote Sens. 2015, 7, 5918-5950. [CrossRef]

59. Eastman, J.R. IDRISI Kilimanjaro: Guide to GIS and Image Processing; Clark University: Worcester, MA, USA, 2003; Volume 1, pp. 87-131.

60. Feng, Y.; Tong, X. Dynamic land use change simulation using cellular automata with spatially nonstationary transition rules. GIScience Remote Sens. 2018, 55, 678-698. [CrossRef]

61. Han, Y.; Jia, H. Simulating the spatial dynamics of urban growth with an integrated modeling approach: A case study of Foshan, China. Ecol. Model. 2017, 353, 107-116. [CrossRef]

62. Akın, A.; Sunar, F.; Berberoğlu, S.; Akin, A.; Sunar, F.; Berberoğlu, S.; Akın, A.; Sunar, F.; Berberoğlu, S. Urban change analysis and future growth of Istanbul. Environ. Monit. Assess. 2015, 187, 506. [CrossRef] [PubMed]

63. McHugh, M.L. Lessons in biostatistics Interrater reliability: The kappa statistic. Biochem. Med. 2012, 22, 276-282. [CrossRef]

64. Omar, N.Q.; Sanusi, S.A.M.; Hussin, W.M.W.; Samat, N.; Mohammed, K.S. Markov-CA model using analytical hierarchy process and multiregression technique. In Proceedings of the IOP Conference Series: Earth and Environmental Science, Kuala Lumpur, Malaysia, 22-23 April 2014; Volume 20.

65. Pontius, R.G.; Millones, M. Death to Kappa: Birth of quantity disagreement and allocation disagreement for accuracy assessment. Int. J. Remote Sens. 2011, 32, 4407-4429. [CrossRef]

66. Memarian, H.; Kumar Balasundram, S.; Bin Talib, J.; Teh Boon Sung, C.; Mohd Sood, A.; Abbaspour, K.; Balasundram, S.K.; Talib, J.B.; Teh, C.; Sung, B.; et al. Validation of CA-Markov for Simulation of Land Use and Cover Change in the Langat Basin, Malaysia. J. Geogr. Inf. Syst. 2012, 04, 542-554. [CrossRef]

67. Foody, G.M. Status of land cover classification accuracy assessment. Remote Sens. Environ. 2002, 80, $185-201$. [CrossRef]

68. Gashaw, T.; Tulu, T.; Argaw, M.; Worqlul, A.W. Evaluation and prediction of land use/land cover changes in the Andassa watershed, Blue Nile Basin, Ethiopia. Environ. Syst. Res. 2017, 6, 17. [CrossRef]

69. Adam, A.G.; Gashu, A. Informal settlements in the peri-urban areas of Bahir Dar, Ethiopia: An institutional analysis. Habitat Int. 2014, 43, 90-97. [CrossRef]

70. Alemu, B.Y. Expropriation, valuation and compensation practice in Ethiopia: The case of Bahir Dar city and surrounding. Prop. Manag. 2013, 31, 132-158.

71. Adam, A.G. Land Tenure in the Changing Peri-Urban Areas of Ethiopia: The Case of Bahir Dar City. Int. J. Urban Reg. Res. 2014, 38, 1970-1984. [CrossRef] 
72. Angel, S.; Sheppard, S.C.; Civco, D.L. The Dynamics of Global Urban Expansion; World Bank: Washington, DC, USA, 2005; p. 205.

73. Seto, K.C.; Shepherd, J.M. Global urban land-use trends and climate impacts. Curr. Opin. Environ. Sustain. 2009, 1, 89-95. [CrossRef]

74. Mundia, C.N.; Aniya, M. Analysis of land use/cover changes and urban expansion of Nairobi city using remote sensing and GIS. Int. J. Remote Sens. 2005, 26, 2831-2849. [CrossRef]

75. Schneider, A.; Woodcock, C.E. Compact, dispersed, fragmented, extensive? A comparison of urban growth in twenty-five global cities using remotely sensed data, pattern metrics and census information. Urban Stud. 2008, 45, 659-692. [CrossRef]

76. Seto, K.C.; Dhakal, S.; Bigio, A.; Blanco, H.; Delgado, G.C.; Dewar, D.; Huang, L.; Inaba, A.; Kansal, A.; Lwasa, S. Human Settlements, Infrastructure and Spatial Planning; Cambridge University Press: Cambridge, UK, 2014.

77. Liu, Z.; Yang, Y.; He, C.; Tu, M. Climate change will constrain the rapid urban expansion in drylands: A scenario analysis with the zoned Land Use Scenario Dynamics-urban model. Sci. Total Environ. 2019, 651, 2772-2786. [CrossRef]

78. Liu, X.; Derudder, B.; Wu, K. Measuring Polycentric Urban Development in China: An Intercity Transportation Network Perspective. Reg. Stud. 2016, 50, 1302-1315. [CrossRef]

79. Liu, X.; Derudder, B.; Wang, M. Polycentric urban development in China: A multi-scale analysis. Environ. Plan. B Urban Anal. City Sci. 2018, 45, 953-972. [CrossRef]

80. Meyfroidt, P.; Lambin, E.F.; Erb, K.H.; Hertel, T.W. Globalization of land use: Distant drivers of land change and geographic displacement of land use. Curr. Opin. Environ. Sustain. 2013, 5, 438-444. [CrossRef]

81. Feuillet, T.; Charreire, H.; Menai, M.; Salze, P.; Simon, C.; Dugas, J.; Hercberg, S.; Andreeva, V.A.; Enaux, C.; Weber, C.; et al. Spatial heterogeneity of the relationships between environmental characteristics and active commuting: Towards a locally varying social ecological model. Int. J. Health Geogr. 2015, 14, 12. [CrossRef] [PubMed]

82. Vermeiren, K.; Vanmaercke, M.; Beckers, J.; Van Rompaey, A. ASSURE: A model for the simulation of urban expansion and intra-urban social segregation. Int. J. Geogr. Inf. Sci. 2016, 30, 2377-2400. [CrossRef]

(C) 2020 by the authors. Licensee MDPI, Basel, Switzerland. This article is an open access article distributed under the terms and conditions of the Creative Commons Attribution (CC BY) license (http://creativecommons.org/licenses/by/4.0/). 